Article

\title{
Effects of the Type of CSR Discourse for Utilitarian and Hedonic Services
}

\author{
Andrea Pérez *D, María del Mar García de los Salmones and Elisa Baraibar-Diez \\ Business Administration Department, University of Cantabria, 39005 Santander, Spain; \\ mariadelmar.garcia@unican.es (M.d.M.G.d.1.S.); elisa.baraibar@unican.es (E.B.-D.) \\ * Correspondence: andrea.perezruiz@unican.es
}

Received: 25 May 2020; Accepted: 5 June 2020; Published: 12 June 2020

\begin{abstract}
In a context of corporate social responsibility (CSR) communication, we explore whether the use of expositive versus narrative discourses interacts with the type of service commercialized by the company (utilitarian vs. hedonic) to determine consumer perceptions and responses to corporate communication. Our main proposal is that, as representative examples of utilitarian services, banking companies would benefit significantly from communicating their CSR efforts with expositive discourses, whereas narrative discourses would be more adequate for hedonic services (e.g., catering). To test the research hypotheses, we use a 2 (expositive/narrative discourse) x 2 (utilitarian/hedonic service) between-subjects experimental design where we expose 302 consumers to different combinations of CSR messages and we evaluate changes in their message attributions and internal and external responses to them. The findings show that the interaction effect is significant and it works in the expected direction for issue importance, CSR fit, and CSR attributions. However, for CSR impact, attitude, trust, purchase, and advocacy intentions, the findings suggest that narrative discourses work better than expositive discourses both for utilitarian and hedonic services. No significant differences between types of discourses are observed for CSR motives, CSR commitment, and C-C identification and the interaction effect is also not significant for these variables.
\end{abstract}

Keywords: CSR; communication; discourse; exposition; narrative; storytelling; banking; catering; utilitarian service; hedonic service

\section{Introduction}

Since the 2008 Great Recession, increasing attention has been devoted to corporate social responsibility (CSR). Not only has the international community realized the importance of achieving sustainable economic, social, and environmental development for stability and progress in the world economy [1], but CSR has also become paramount for institutions and companies to recover credibility, trust, and reputation $[2,3]$.

Nonetheless, it is noticeable that the business returns to CSR are contingent on stakeholders' awareness of a company's CSR activities [4]. However, studies frequently report that CSR awareness is typically low, while stakeholders also demonstrate to be highly skeptical of the CSR motives behind companies that engage in CSR efforts [5]. These ideas highlight the necessity that companies have nowadays to design better communication strategies to reap strategic benefits from its CSR activities [4]. The way companies design their CSR communication strategies is crucial for the success of CSR and research should focus on this issue to provide companies with useful insight to design CSR and communication strategies more adequately.

For instance, an interesting line of research has focused on exploring the effect that different discourse strategies have on audiences when exposed to communication [6-8]. Scholars have frequently discussed the advantages and disadvantages of designing messages based on expositive 
(semantic or rational) or narrative (i.e., storytelling) discourses $[9,10]$. Based on the premises of the narrative paradigm theory (NPT) [11], scholars have mostly defended that discourse will always tell a story and insofar as it invites an audience to believe it or to act on it, the narrative paradigm and its attendant logic, narrative rationality, are available for (better) interpretation and assessment. Therefore, narrative discourses are expected to report better outcomes for companies than expositive discourses [12-14]. Nonetheless, the empirical evidence along this line of research is largely inconclusive [15], with studies alternatively demonstrating the superior performance of expositive [16] or narrative [15] discourses, or even showing mixed results within the same experiments [17].

Some scholars have suggested that the inconclusiveness of previous findings may be due to the existence of an interaction effect between the type of discourse strategy and the type of product/service context of the company [17-19]. More precisely, scholars suggest that the type of discourse chosen by the company in its communications should match their product/service type to be successful [15]. For instance, banking services are utilitarian services that, based on the premises of the elaboration likelihood model (ELM), would benefit from applying rational nonnarrative appeals to their communications [20]. On the contrary, catering services are hedonic services, which are focused on pleasing consumers and, consequently, would benefit more from emotional narrative discourses [20]. Nevertheless, support for this matching principle is again contradictory and little consensus has been reached yet. As an example, in her qualitative study, Mortimer (2008) observed that narrative discourses could be useful for both hedonic and utilitarian services and that the matching of the discourse strategy to the type of service context was not necessarily an adequate communication approach for companies [15].

Along this line of research, we have observed that the lack of conclusive findings on the matching principle between the type of discourse and the type of service is especially evident in the CSR communication literature, where very few studies have tested this interaction effect [21]. All the papers discussed above have explored the role of the type of discourse and/or the service context in conventional commercial advertising (i.e., communication focused on presenting the products and services that can solve a consumer's problem), whereas very little research has been implemented so far in the CSR context. Nonetheless, CSR communication differs from commercial advertising significantly because its main goal is not to "sell" products/services but to promote corporate sustainable development endeavors and define corporate values and personality [22]. It also differs from commercial advertising because of its normative or moralistic character. Therefore, the few conclusions (if any) that could be extracted from previous literature on the interaction effect between the type of discourse and the type of service could not be translated into the CSR literature straightforwardly and, as so, further research is needed in the context of CSR communication.

Based on these ideas, the research goal of the present paper is to explore whether the use of expositive versus narrative discourses interacts with the type of service (utilitarian vs. hedonic) to determine consumer perceptions and responses to CSR communication. To propose our research hypotheses, we base on the ELM [23] and the distinction between functional and self-congruity types of message processing $[15,18]$ to propose that utilitarian (banking) services would benefit significantly from communicating their CSR efforts with expositive discourses, whereas narrative discourses should be left for hedonic (catering) services that would achieve better results with them. To measure the consequences of the interaction effect, we evaluate changes in consumer message attributions and internal and external responses to a CSR message [4] in a $2 \times 2$ experimental context where consumers are exposed to different combinations of expositive vs. narrative messages in utilitarian vs. hedonic service contexts. In testing this proposal, the paper will contribute to previous literature in two ways. First, the paper will provide further insight into the discourse by service interaction effect that has reported inconclusive findings in previous literature. Second, it will do so in the context of CSR communication, where previous literature has largely neglected the possibility of an interaction effect between both conditions. 
We structure the paper as follows. First, we revise literature on discourse and communication strategies and types of services to propose the research hypotheses of the study. Second, we describe the research method, paying special attention to its design, sample, and measurement scales. Third, we describe the main findings of the paper and we discuss them in the light of previous literature. We conclude by presenting the most relevant implications, limitations, and future lines of research derived from the study.

\section{Literature Review}

\subsection{Expositive and Narrative Discourses in Corporate Communication}

An extensive line of research in marketing and communication literature suggests that the success of corporate communication largely depends on the type of discourse used by companies in their public messages $[6,8]$. In this regard, designing a message that will be perceived as rational, emotional, or mixed in its discourse is a primary strategic consideration in corporate communication [24].

Along this line, companies have traditionally applied two opposite types of discourses to their corporate communications; they present messages that are mostly expositive or narrative in character [9,10]. Expositive (semantic, rational, or nonnarrative) perspectives on communication include "self-evident propositions, demonstrations, proofs, and verbal expressions of certain and probable knowing" [7]. Thus, exposition mainly bases on the description of rational arguments, statistics, numbers, names, and facts [12]. Expositive messages do not go any deeper into the reality behind those numbers and they avoid emotional connotations as much as possible [9]. In numerous occasions, this approach has been referred to as informational communication [15]. On the contrary, the narrative (storytelling) rationality implies that "facts need some narrative to bind them together to enhance their intelligibility" [7]. In narrative messages, companies may use storytelling, which refers to the art of telling emotional stories to engage with the audience. Corporate storytelling is the "practice of using narration from within the organization relating to its people, practices, policies and visions to effectively engage with staff (and external stakeholders)" [25]. Thus, narrative messages are aimed at generating emotional connections between stakeholders and companies [26,27] by adding favorable and unique associations to companies through messages that can better embrace the core corporate values [27].

Based on the narrative paradigm theory (NPT) [11], previous research has mostly defended that people tend to think narratively more than paradigmatically or in an expositive way [20]. Therefore, narrative discourses are expected to lead to better audience responses than expositive discourses [12-14]. Consisting of a sequence of story—understanding—shared meaning, storytelling, materialized in a compelling story, gains access to the mind and sensations of those who are listening or watching, enriched in their learning and feelings. This connection provokes empathy and, therefore, it allows the audience to understand and be sensitive to the experience that they are being told about, which derives into better attitudes and allows the formation of stronger relationships and engagement [28].

Nonetheless, empirical evidence is inconclusive when it comes to corroborating the role of expositive and narrative discourses on consumers' message attributions and responses to corporate communication. For instance, Mortimer (2008) examined a sample of service advertisements that had been recognized for their success and she found that the majority of advertisements utilized emotional discourses [15]. On the contrary, in a study that explored retail services advertising, Stafford and Day (1995) found the main effect for discourse across industries, in which rational discourses led to more positive levels of attitude towards the ad than emotional discourses [16]. Hill et al. (2004) tested the hypothesis that a successful visualization advertising strategy (i.e., an ad based on a narrative discourse) evoked clear and vivid mental images of the service on consumers, thus making CSR communication more successful [17]. However, their findings only supported this hypothesis for some outcomes such as perceived informativity, service quality, and likelihood to use, but it was not supported for perceived uniqueness. 


\subsection{Interaction Effect between Discourse Strategy and Type of Service}

A plausible explanation for the inconclusiveness of previous literature is that responses to corporate communication do not only depend on the type of discourse adopted by the company, but also on the type of service context where the company operates [15-17,21]. Generally, in service literature, scholars differentiate between utilitarian and hedonic services $[16,20]$. For instance, banking services are utilitarian services that provide functional utilities, deliver cognitive benefits, and are characterized by low employee contact, moderate customization, an equipment-orientation, and direction toward things $[16,20]$. On the contrary, catering services are hedonic services that are consumed primarily for affective or sensory gratification purposes, provide consumers with emotions, and are characterized by high employee contact, considerable customization, and an orientation toward people, not things (i.e., they are more personal) $[16,20]$.

Based on the elaboration likelihood model (ELM) [23] and the functional congruity and self-congruity types of message processing $[15,18]$, we propose that an expositive discourse is especially adequate for communicating about the CSR of banking (utilitarian) services, whereas narrative approaches would be more suitable for the CSR communication of catering (hedonic) services.

In this regard, banking services are high-involvement services for consumers [29] and, as such, the amount this audience type would think about a message coming from a banking company would be high. Um (2008) shows that elaboration is higher when the argument is relevant to the person (i.e., high involvement), and lower when the argument is irrelevant [30]. Therefore, in the case of a banking company, persuasion is most commonly achieved through central and functional processing routes $[15,24]$, which occur when the person who receives the information is likely to focus and process the finer points in the message (e.g., the quality of the argument) $[18,24]$. Therefore, for banking services, communicating CSR facts with a rational, expositive discourse would be more adequate than using a narrative, storytelling discourse because, as utilitarian services, the functional aspects of consumption are more important and rational decision is dominant over emotional responses [31]. Consumers evaluate utilitarian services using cognitive criteria [20]. This rationale matches the use of expositive discourses, which assume that consumers make rational decisions and, therefore, they prefer nonnarrative messages [21].

On the contrary, in catering services, the hedonic aspect of consumption is highly important and affective responses may overwhelm cognitive responses [31]. Catering services are value-expressive, which means that consumers will generally make their decisions to use the service based on the image that is associated to the company and the association that will be created between the company's image and his/her image [18]. Consumers are expected to be influenced by this type of hedonic service more at a personal level, making it difficult for them to disassociate themselves from the service and perceiving it as an extension of themselves [19]. Therefore, when the service is value-expressive, audience persuasion is influenced through an affective, peripheral, and self-congruity processing route [18], which occurs when the person focuses more lightly on source cues to form their attitudes [18] because these cues require little mental effort [24]. In this context, narrative discourses will be more adequate than expositive discourses. In this regard, "well-designed, well-told stories convey both information and emotion, both the explicit and the tacit, both the core and context" [32]. CSR stories have an ameliorative effect, enhancing the ability of audiences to exist more meaningfully and improve their mental models of others and themselves [33]. Thus, corporate storytelling generates an emotional connection between consumers and companies [26,27] and, consequently, it is expected to intensify consumer positive responses to CSR messages when they evaluate hedonic services.

\subsection{Message Attributions in CSR Communication}

To explore how the interaction between type of discourse and type of service affects consumer perceptions and responses to CSR communication, we test the differentiated effect of CSR messages on the prominent framework of CSR communication developed by Du et al. (2010) [4]. According to these authors, one key aspect to create stakeholder awareness and managing stakeholder 
perceptions of a company's CSR activities is the message content (i.e., the "what to communicate" question). Du et al. (2010) and subsequent researchers who have tested their conceptual framework empirically [34], defend that the content of a CSR message should emphasize: (a) the importance of the social issue, (b) the impact the company has on the cause, (c) the motives why it engages in the social cause, (d) the fit (i.e., congruence, similarity, compatibility) between the cause and the company, and (e) the company's long-term commitment to the cause.

Issue importance refers to the relevance of the social cause on a global scale. When companies include information about issue importance in the CSR message, they increase stakeholders' awareness of the cause, which will improve message diagnosticity, allow stakeholders to effectively process CSR appeals and, consequently, improve responses to the CSR message [35,36].

CSR impact reflects the results of the collaboration between the company and the social cause, that is, the impact the company has achieved on the social cause over the time they have collaborated. Mentioning CSR impact gives the message an objective charge, it enhances its credibility, and it let stakeholders evaluate the true level of a company's CSR involvement and commitment to the social cause, which can lead to positive communication outcomes [4,37].

As for CSR motives, it is generally agreed that the perception of a company's intrinsic (altruistic) motives to collaborate with a social cause increases perceived sincerity and positive emotions, whereas a behavior attributed only to extrinsic (egoistic) motives is perceived as dishonest, opportunistic, and misleading for stakeholders, arousing negative feelings $[38,39]$. Literature also defends that perceptions of corporate altruistic motives lead stakeholders to understand the company's commitment to the social cause as more lasting and stable over time [40] because it derives from the company's value system directly [41].

CSR fit refers to the congruence between the social cause and the company, which can be functional (i.e., the congruence of the type of product/service marketed by the company, and the type of social cause supported) or based on image cues (i.e., the holistic, symbolic, and peripheral judgement of company identity and its relatedness and similarity to the cause identity) [42-44]. A good cause-company fit may minimize negative judgments about the company's motives to collaborate with the cause [45] and, therefore, it leads to better communication outcomes [4,46]. On the contrary, a low perceived fit is likely to increase cognitive elaboration and make egoistic motives more salient, arousing negative feelings toward CSR messages [44].

Finally, CSR commitment relates to the company's long-term commitment to the social cause. CSR commitment improves stakeholders' responses because a long-term commitment (versus a reactive, shorter-term CSR action) provides more time to learn about a company-cause collaboration [4]. It also reflects a genuine concern for increasing community welfare and, consequently, it improves attitudes towards the company [35].

As reported in the previous section of this paper, we expect that these consumer perceptions of the message content are dependent upon the interaction between type of discourse (expositive vs. narrative) and type of service (utilitarian vs. hedonic) $[15,16,18,21]$. Thus, we hypothesize that consumers will perceive the different components of the CSR message discussed by Du et al. (2010) differently in each industry depending on the type of CSR discourse used by companies. Based on this idea, this study tests the following research hypotheses:

H1: In a utilitarian service context, an expositive CSR discourse generates statistically significant higher perceptions of (a) issue importance, (b) CSR impact, (c) CSR motives, (d) CSR fit, and (e) CSR commitment than a narrative CSR discourse.

H2: In a hedonic service context, a narrative CSR discourse generates statistically significant higher perceptions of (a) issue importance, (b) CSR impact, (c) CSR motives, (d) CSR fit, and (e) CSR commitment than an expositive CSR discourse. 


\subsection{Consumer Responses to CSR Communication}

Then, message attributions generate internal and external outcomes among stakeholders, which refer respectively to their attitudinal and behavioral responses to the company's CSR communication strategy [4,34]. As stated by $\mathrm{Du}$ et al. (2010), when analyzing consumer responses specifically, internal outcomes mainly include CSR attributions, service brand attitude, consumer-company (C-C) identification, and trust, whereas external outcomes refer to purchase and advocacy intentions [4].

CSR communication makes consumers aware of such initiatives, then, it derives in positive CSR attributions [21]. Therefore, corporate communications are important in raising CSR attributions among consumers to induce positive attitudes and behavioral intentions. Without this sort of communication, consumers will purchase a similar service that does not have such CSR attributes [21].

Along with CSR awareness (i.e., associations), Keller (1998) considers that to gain consumer-based brand equity, the consumer should also hold brand associations that are strong, favorable, and unique in comparison to other brands offered in the same category [47]. These brand associations refer to service brand attitude as described by Du et al. (2010) [4]. A large component of Keller's (1998) model depicts various types of brand associations in the form of service-related and non-service-related attributes, such as CSR [48]. Improving brand attitude is important for companies because it is linked to the consumer intention to use the service directly [49].

C-C identification refers to the cognitive and affective state of connection that a consumer perceives between him/herself and a company because of the identification of substantial overlap between the consumer's perceptions of his/her identity and the perceptions of the company's identity [50]. A company that is skilled in meeting the consumer's needs for self-definition is also a company the consumer is satisfied with because $\mathrm{C}-\mathrm{C}$ identification provides a more favorable context for consumers to respond to corporate performance experiences as against to prior expectations. In addition, the higher C-C identification, the higher consumer loyalty and the wish to establish long-term relationships with the company [51].

Trust is understood as the existence of a bidirectional relationship where one exchange partner (consumer) believes in the other's (company) reliability and integrity [52]. Achieving consumer trust is especially important for companies because it serves as a key driver of consumer retention strategies, especially in retail service markets. Along this line, in numerous occasions, research has confirmed the link between trust and other relevant outcomes of corporate strategies such as perceived value, purchase, advocacy, and loyalty $[53,54]$.

Purchase intentions refer to consumer commitment to buy goods or use services from a company over time [55]. Therefore, it reflects a deeply held commitment of consumers to repurchase from the company [56]. Purchase intentions have always been defended as the primary criteria used by companies to assess the adequacy of their consumer retention strategies [57].

Finally, advocacy intentions refer to consumer positive word-of-mouth, that is, informal communication directed at other consumers about products, services, and companies [58]. Advocacy has a large influence on people close to the consumer because it may encourage them to also show interest in the company and buy its products or services [55].

Based on the interaction effect suggested in this study, the following research hypotheses are proposed:

H3: In a utilitarian service context, an expositive CSR discourse generates a statistically significant higher level of (a) CSR attributions, (b) service brand attitude, (c) C-C identification, (d) trust, (e) purchase intentions, and $(f)$ advocacy intentions than a narrative CSR discourse.

H4: In a hedonic service context, a narrative CSR discourse generates a statistically significant higher level of (a) CSR attributions, (b) service brand attitude, (c) C-C identification, (d) trust, (e) purchase intentions, and ( $f$ ) advocacy intentions than an expositive CSR discourse. 


\section{Method}

\subsection{Research Design}

To test the research hypotheses, we used a 2 (expositive/narrative discourse) $\times 2$ (utilitarian/hedonic service) between-subjects experimental design.

We collected data in a northern city in Spain (i.e., Santander, Cantabria) between April and July 2018, after we had properly trained research assistants for the task. Each research assistant was assigned randomly to collect data in one of the four experimental conditions. We used a convenience sampling procedure based on gender and age to select respondents and assign them to each scenario. In total, 302 participants took place in the experiment and they were distributed across scenarios as shown in Table 1 . The sample comprised $49.7 \%$ women and 50.3\% men. Participants' age ranged from 19 to 90. More precisely, $22.2 \%$ of the participants were younger than $35,38.7 \%$ were between 35 and 55 , and $39.1 \%$ were older than 55 . Sampling quotas were very similar in the four scenarios and they were representative of the population in the Spanish region where data was collected.

Table 1. Sample sizes.

\begin{tabular}{ccc}
\hline Service Type & Discourse Strategy & $\mathbf{n}$ \\
\hline Utilitarian (bank) & Expositive & 75 \\
& Narrative & 75 \\
\hline Hedonic (restaurant) & Expositive & 76 \\
& Narrative & 76 \\
\hline
\end{tabular}

For each scenario, research assistants gave short explanations to the participants before the procedure started. The explanations did not convey the real purpose of the study. Instead, participants were told that the purpose was to understand their level of interest in CSR activities. Participants became aware of a fictitious company and its CSR program by evaluating website content (Appendix A, Figures A1 and A2). The experiment contained stimuli from fictitious websites portraying information on the CSR activities implemented by the company over the last year, which were focused especially on the fight against childhood leukemia in two service contexts: a bank (utilitarian) and a restaurant (hedonic).

We purposely used fictitious stimuli to control for participants' knowledge, attitudes, and behavioral intentions concerning real companies, therefore avoiding their influence on the conceptual model proposed in this study [59]. We focused on the website for several reasons. First, website audiences generally perceive home pages primarily as an advertisement designed to entice them to experience the site [24]. Thus, communication theory matches this online context well. Second, a website is the most frequent medium used to engage in CSR communication because it provides a highly accessible but inexpensive medium to avoid accusations of spending more on communication than on the CSR activities themselves [38]. Third, websites are a preferred medium to communicate CSR commitment because of the richness of argumentation and opportunities for interactivity they provide [38]. We chose childhood leukemia as the social cause of our study based on previous studies that had considered health as a critical issue for CSR assessment [60].

To avoid potential confounding effects, all experimental website content used the same images and structure so that the only difference between them was the company itself and the discourse strategy used to present the information [61]. In the four treatments, information about key characteristics of the focal company and its CSR activities (e.g., numbers, figures) were kept constant. The website content conveyed that "Your Bank" (bank, utilitarian service) or "Ecofood" (restaurant, hedonic service) had invested " $x$ " amount of money to collaborate with the childhood leukemia cause and it had achieved " $x$ " results because of the collaboration during the last year. In the narrative treatments, the company's CSR activities were described through an emotional story that involved the son of a company's employee who suffered from childhood leukemia. In the expositive treatments, the same 
information was described, although this time it was presented objectively and in a rational way, with bullet points, only using facts, figures, and statistics, and without referring to the employee's son who suffered from the disease.

Participants were asked to read the fictitious information about the company and its CSR website at their own pace. After reading it, they had to complete a questionnaire that included manipulation and post-test measures. The experiment included a manipulation check to test for perceived differences between utilitarian and hedonic services in terms of competence (expert vs. inexperienced/competent vs. incompetent) [62] and attractiveness (attractive vs. unattractive/pleasant vs. unpleasant) [62]. Utilitarian services usually rate higher in functional components than emotional components of customer experience and companies offering this type of services tend to be perceived as more competent and experienced than companies providing hedonic services [63]. On the contrary, participants were expected to perceive hedonic services as more delightful, enjoyable, and attractive than utilitarian services [21]. A manipulation check to evaluate message authenticity (The information presented in the website seems able to occur in the real world/is authentic/provides an abundance of facts so that I believe it is authentic) [64] and participants' skepticism towards the information presented in the websites (Claims are exaggerated/are intended to mislead/are not believable/are not true) [65] tested for perceived differences between expositive and narrative discourses. Expositive discourses do not go deep into the reality behind the rational arguments, statistics, numbers, names, and facts that they provide [12]. On the contrary, CSR stories make social causes much more real to the audience and they make the messages more convincing and memorable [26]. Therefore, they are expected to be more authentic and elicit less skepticism than expositive discourses. Measurement of all items took place on seven-point Likert-type and semantic differential scales.

\subsection{Measurement Scales}

Seven-point Likert-type and semantic differential scales were used to evaluate post-test measures. We measured issue importance with the three-item scale proposed by Russell and Russell (2010) [66]. To measure CSR impact, we applied the five-item scale proposed by Connors et al. [67]. CSR motives were evaluated by adopting the three-item scale originally proposed by Becker-Olsen et al. [68] The five-item scale used to measure CSR fit was adapted from Speed and Thompson (2000) and Skard and Thorbjornsen (2014) [69,70]. We measured CSR commitment using a five-item scale taken from Walton (2014) [71]. CSR attributions were measured with a three-item scale taken from Wagner et al. (2009) [72]. We evaluated service brand attitude with the four-item scale also proposed by Wagner et al. (2009) [72]. To measure C-C identification, we applied the five-item scale proposed by Currás (2007) [62]. To measure trust, we used the three-item scale proposed by Morgan and Hunt (1994) [52]. Finally, we evaluated purchase and advocacy intentions with two three-item scales adapted from the original proposals of Groza et al. (2011) and Romani et al. (2013), respectively $[73,74]$. Table 2 presents all the items.

When building the questionnaire, we also discussed sources of common method variance (CMV), such as social desirability bias, to refine the gathering of empirical data [75]. To avoid the transient mood state of the participants, we aimed at reducing evaluation apprehension by guaranteeing anonymity. For this purpose, we instructed the research assistants to assure the participants that their answers were anonymous and that there were no right or wrong answers. In doing so, the participants were encouraged to answer questions as honestly as possible [75]. After collecting data, we also applied statistical analyses to control for CMV. More precisely, we conducted Harman's single-factor test, which corroborated that all the scales items loaded on more than one single factor. Therefore, they were not concentrated in any one general factor, which corroborated that the correlation among variables was not influenced by their common source [75]. Thus, CMV did not influence the findings of our quantitative research significantly. 
Table 2. Measurement scales.

\begin{tabular}{|c|c|}
\hline \multicolumn{2}{|r|}{ Message Attributions } \\
\hline Factors & Items \\
\hline Issue importance & $\begin{array}{c}\text { IMPO1) The company transmits that this is an important cause; IMPO2) The } \\
\text { company transmits it is vital to tackle this cause; IMPO3) The company transmits that } \\
\text { companies have a responsibility to address this cause } \\
\text { The information presented on the website is ... }\end{array}$ \\
\hline Impact & $\begin{array}{c}\text { IMPA1) Abstract/Concrete; IMPA2) Ambiguous/Clear; IMPA3) Not } \\
\text { descriptive/Descriptive; IMPA4) Not vivid/Vivid; IMPA5) Not easy to imagine/Easy } \\
\text { to imagine }\end{array}$ \\
\hline Motives & $\begin{array}{l}\text { The motivations of the company to support the cause are ... } \\
\text { MOTI1) Self-interested/Community interested; MOTI2) }\end{array}$ \\
\hline Fit & $\begin{array}{l}\text { Firm-focused/Customer-focused; MOTI3) Profit-motivated/Socially-motivated } \\
\text { FIT1) The image of the cause and the image of the company are similar; FIT2) The } \\
\text { company and the cause fit together well; FIT3) The company and the cause stand for } \\
\text { similar things; FIT4) It makes sense to me that the company sponsors this cause; FIT5) }\end{array}$ \\
\hline Commitment & $\begin{array}{l}\text { There is a logical connection between the cause and the company } \\
\text { COMM1) The company seems to feel strongly about helping the cause; COMM2) The } \\
\text { company demonstrates a real interest in making an impact to help the cause; } \\
\text { COMM3) The company is capable of long-lasting beneficial effects towards the cause; } \\
\text { COMM4) The company seems like they will support the cause for a long period; } \\
\text { COMM5) The company will more than likely make a large impact toward helping the } \\
\text { cause }\end{array}$ \\
\hline \multicolumn{2}{|r|}{ Consumer Responses } \\
\hline Attributions & $\begin{array}{l}\text { ATTR1) The company is socially responsible; ATTR2) The company is concerned to } \\
\text { improve the well-being of society; ATTR3) The company follows high ethical } \\
\text { standards }\end{array}$ \\
\hline Attitude & $\begin{array}{c}\text { My general feeling towards the company is ... } \\
\text { ATTI1) Unfavorable/Favorable; ATTI2) Bad/Good; ATTI3) Unpleasant/Pleasant; } \\
\text { ATTI4) Negative/Positive }\end{array}$ \\
\hline Identification & $\begin{array}{l}\text { IDEN1) My way of being sticks with what I perceive from the company; IDEN2) I } \\
\text { look like what I think the company represents; IDEN3) I am similar to how I perceive } \\
\text { the company; IDEN4) The image I have of the company matches the image I have of } \\
\text { myself; IDEN5) The company's identity resembles my identity }\end{array}$ \\
\hline Trust & $\begin{array}{c}\text { TRUS1) The company can be trusted; TRUS2) The company can be counted on to do } \\
\text { what is right; TRUS3) The company has high integrity } \\
\text { If the company existed, how likely would it be that you purchased its services? }\end{array}$ \\
\hline Purchase & $\begin{array}{c}\text { ?PURC1) Very unlikely/Very likely; PURC2) Improbable/Probable; PURC3) } \\
\text { Impossible/Possible }\end{array}$ \\
\hline Advocacy & $\begin{array}{l}\text { ADVO1) I intend to say positive things about the company to friends, relatives and } \\
\text { other people; ADVO2) I intend to mention favorable things about the company with } \\
\text { my friends, relatives, or other people; ADVO3) I intend to recommend to purchase } \\
\text { services of the company to my friends, relatives, and other people }\end{array}$ \\
\hline
\end{tabular}

\section{Findings}

\subsection{Manipulation Checks}

We performed two independent-samples t-tests on the manipulation check questions to verify if the participants rated corporate competence and attractiveness and message authenticity and skepticism differently in the alternative experimental conditions. As per expectations, the participants perceived the hedonic service to be more attractive (meanU $=5.090$, meanH $=5.880 ; t=4.983, p<0.050$ ) and pleasant (meanU $=5.190$, meanH $=5.970 ; t=5.369, p<0.050$ ) than the utilitarian service, whereas there were no significant differences in the competence dimension (meanU $=5.050$, meanH $=5.303 ; t=1.953$, $p>0.050$ ), where both types of services were perceived equally expert (meanU $=5.010$, meanH $=5.180$; $\mathrm{t}=1.268, p>0.050$ ). Although the test did not report significant differences concerning skepticism towards the message (meanE $=3.171$, meanN $=2.901 ; \mathrm{t}=1.808, p>0.050$ ), the narrative discourse was perceived to be more realistic (meanE $=5.170$, meanN $=5.480 ; \mathrm{t}=2.210, p<0.050$ ) and authentic (meanE $=4.890$, meanN $=5.300 ; \mathrm{t}=2.822, p<0.050$ ) and to provide more abundance of authentic 
facts $($ meanE $=4.900$, meanN $=5.330 ; t=2.894, p<0.050)$ than the expositive message. Therefore, the results indicated that the experimental manipulation was successful because the different scenarios were perceived differently by the participants.

\subsection{Evaluation of the Measurement Scales}

We implemented a first-order confirmatory factor analysis (CFA) to analyze the psychometric properties of the measurement scales. To evaluate the quality of all the indicators that are explained in this section, we followed the recommendations of Hair et al. (2014) [76].

Table 3 shows the results of the analysis implemented with the scales that measured message attributions. The findings corroborated that all the comparative fit indexes were very close or exceeded the recommended value of 0.900 , thus corroborating the goodness of the model fit (NFI $=0.897$, $\mathrm{NNFI}=0.932, \mathrm{CFI}=0.943, \mathrm{IFI}=0.943$ ). The root mean square error of approximation (RMSEA) value was also below the maximum limit of 0.080 recommended in the literature (RMSEA $=0.060$ ). Additionally, scales yielded acceptable psychometric properties: factor loadings were greater than 0.500 , composite reliability (CR) indicators were greater than 0.700 , average variance extracted (AVE) indicators were greater than 0.500 , and these AVE indicators were also greater than the squared correlation with any other construct.

Table 3. Confirmatory factor analysis (CFA) message attributions $(n=302)$.

\begin{tabular}{|c|c|c|c|c|c|c|c|}
\hline Factors & Items & Mean & s.d. & $\lambda$ & $\mathbf{R} 2$ & CR & AVE \\
\hline \multirow{3}{*}{ Issue importance } & IMPO1 & 5.680 & 1.239 & 0.804 & 0.647 & \multirow{3}{*}{0.869} & \multirow{3}{*}{0.690} \\
\hline & IMPO2 & 5.520 & 1.296 & 0.904 & 0.817 & & \\
\hline & IMPO3 & 5.330 & 1.539 & 0.778 & 0.606 & & \\
\hline \multirow{5}{*}{ CSR impact } & IMPA1 & 5.320 & 1.245 & 0.816 & 0.666 & \multirow{5}{*}{0.875} & \multirow{5}{*}{0.584} \\
\hline & IMPA2 & 5.420 & 1.306 & 0.846 & 0.716 & & \\
\hline & IMPA3 & 4.940 & 1.376 & 0.757 & 0.573 & & \\
\hline & IMPA4 & 4.310 & 1.438 & 0.701 & 0.491 & & \\
\hline & IMPA5 & 5.010 & 1.396 & 0.689 & 0.475 & & \\
\hline \multirow{3}{*}{ CSR motives } & MOTI1 & 4.550 & 1.585 & 0.836 & 0.698 & \multirow{3}{*}{0.895} & \multirow{3}{*}{0.740} \\
\hline & MOTI2 & 4.640 & 1.548 & 0.812 & 0.659 & & \\
\hline & MOTI3 & 4.880 & 1.565 & 0.929 & 0.864 & & \\
\hline \multirow{5}{*}{ CSR fit } & FIT1 & 5.120 & 1.422 & 0.865 & 0.749 & \multirow{5}{*}{0.938} & \multirow{5}{*}{0.753} \\
\hline & FIT2 & 5.160 & 1.465 & 0.895 & 0.802 & & \\
\hline & FIT3 & 5.140 & 1.562 & 0.911 & 0.831 & & \\
\hline & FIT4 & 5.440 & 1.481 & 0.790 & 0.624 & & \\
\hline & FIT5 & 5.530 & 1.550 & 0.874 & 0.764 & & \\
\hline \multirow{5}{*}{ CSR commitment } & COMM1 & 5.350 & 1.285 & 0.633 & 0.400 & \multirow{5}{*}{0.869} & \multirow{5}{*}{0.574} \\
\hline & COMM2 & 5.240 & 1.295 & 0.705 & 0.497 & & \\
\hline & COMM3 & 4.830 & 1.309 & 0.763 & 0.582 & & \\
\hline & COMM4 & 4.800 & 1.404 & 0.830 & 0.689 & & \\
\hline & COMM5 & 5.070 & 1.370 & 0.836 & 0.699 & & \\
\hline
\end{tabular}

Model fit: S-B $\chi 2$ (d.f. $=176)=368.745(p<0.010) ; \mathrm{NFI}=0.897 ; \mathrm{NNFI}=0.932 ; \mathrm{CFI}=0.943 ; \mathrm{IFI}=0.943 ; \mathrm{RMSEA}=0.060$.

Similarly, Table 4 shows the results of the analysis implemented with the scales that measured consumer internal and external responses to CSR communication. These scales also reported acceptable psychometric properties in the analysis. 
Table 4. CFA consumer responses $(n=302)$.

\begin{tabular}{cccccccc}
\hline Factors & Items & Mean & s.d. & $\lambda$ & R2 & CR & AVE \\
\hline \multirow{4}{*}{ Attributions } & ATTR1 & 5.250 & 1.319 & 0.855 & 0.731 & & \\
& ATTR2 & 5.340 & 1.244 & 0.819 & 0.671 & 0.857 & 0.667 \\
& ATTR3 & 5.180 & 1.300 & 0.775 & 0.600 & & \\
\hline \multirow{5}{*}{ Attitude } & ATTI1 & 5.360 & 1.246 & 0.880 & 0.774 & & \\
& ATTI2 & 5.540 & 1.331 & 0.910 & 0.828 & \multirow{2}{*}{0.951} & 0.828 \\
& ATTI3 & 5.530 & 1.375 & 0.946 & 0.894 & & \\
& ATTI4 & 5.590 & 1.348 & 0.902 & 0.814 & & \\
Identification & IDEN1 & 4.750 & 1.375 & 0.802 & 0.643 & & \\
& IDEN2 & 4.620 & 1.373 & 0.892 & 0.795 & & \\
& IDEN3 & 4.540 & 1.475 & 0.934 & 0.873 & 0.945 & \\
& IDEN4 & 4.420 & 1.502 & 0.903 & 0.815 & & \\
& IDEN5 & 4.380 & 1.509 & 0.870 & 0.758 & & \\
\hline \multirow{5}{*}{ Trust } & TRUS1 & 4.630 & 1.318 & 0.852 & 0.726 & & \\
& TRUS2 & 4.900 & 1.210 & 0.875 & 0.766 & 0.894 & \\
& TRUS3 & 4.940 & 1.242 & 0.851 & 0.724 & & \\
\hline \multirow{2}{*}{ Purchase } & PURC1 & 4.750 & 1.412 & 0.859 & 0.738 & & \\
& PURC2 & 4.670 & 1.599 & 0.963 & 0.928 & 0.937 & 0.832 \\
& PURC3 & 4.770 & 1.613 & 0.912 & 0.832 & & \\
\hline \multirow{2}{*}{ Advocacy } & ADVO1 & 5.030 & 1.579 & 0.952 & 0.906 & & \\
& ADVO2 & 5.070 & 1.573 & 0.968 & 0.937 & 0.957 & 0.882 \\
& ADVO3 & 4.880 & 1.624 & 0.896 & 0.803 & & \\
\hline
\end{tabular}

Model fit: S-B $\chi 2$ (d.f. $=173)=353.142(p<0.010) ; \mathrm{NFI}=0.928 ; \mathrm{NNFI}=0.953 ; \mathrm{CFI}=0.962 ; \mathrm{IFI}=0.962 ; \mathrm{RMSEA}=0.059$.

\subsection{Hypotheses Testing}

We contrasted the hypotheses applying multivariate ANOVA (Table 5).

Table 5. Multivariate ANOVA.

\begin{tabular}{|c|c|c|c|c|c|c|c|}
\hline \multirow{2}{*}{ Factors } & \multicolumn{3}{|c|}{ Type of Service (S) } & \multicolumn{3}{|c|}{ Discourse Strategy (D) } & \multirow{2}{*}{$\begin{array}{l}\text { Interaction } \\
\quad(\mathrm{S} \times \mathrm{D})\end{array}$} \\
\hline & Mean (U) & Mean (H) & $F(p)$ & Mean (E) & Mean (N) & $F(p)$ & \\
\hline $\begin{array}{c}\text { Issue } \\
\text { importance }\end{array}$ & 5.202 & 5.809 & $\begin{array}{l}21.258 \\
(0.000)\end{array}$ & 5.351 & 5.665 & $\begin{array}{c}5.579 \\
(0.019)\end{array}$ & $\begin{array}{l}8.228 \\
(0.004)\end{array}$ \\
\hline CSR impact & 4.845 & 5.155 & $\begin{array}{c}6.337 \\
(0.012)\end{array}$ & 4.744 & 5.258 & $\begin{array}{l}17.419 \\
(0.000)\end{array}$ & $\begin{array}{c}0.003 \\
(0.953)\end{array}$ \\
\hline CSR motives & 4.331 & 5.050 & $\begin{array}{l}20.861 \\
(0.000)\end{array}$ & 4.539 & 4.848 & $\begin{array}{c}3.884 \\
(0.059)\end{array}$ & $\begin{array}{c}1.624 \\
(0.203)\end{array}$ \\
\hline CSR fit & 4.785 & 5.758 & $\begin{array}{l}47.898 \\
(0.000)\end{array}$ & 5.099 & 5.450 & $\begin{array}{c}6.113 \\
(0.014)\end{array}$ & $\begin{array}{l}14.590 \\
(0.000)\end{array}$ \\
\hline $\begin{array}{c}\text { CSR } \\
\text { commitment }\end{array}$ & 4.812 & 5.303 & $\begin{array}{l}16.215 \\
(0.000)\end{array}$ & 4.958 & 5.160 & $\begin{array}{c}2.762 \\
(0.098) \\
\end{array}$ & $\begin{array}{c}0.038 \\
(0.845) \\
\end{array}$ \\
\hline Attributions & 4.896 & 5.614 & $\begin{array}{l}34.802 \\
(0.000)\end{array}$ & 5.108 & 5.406 & $\begin{array}{l}5.903 \\
(0.016)\end{array}$ & $\begin{array}{c}6.823 \\
(0.009)\end{array}$ \\
\hline Attitude & 4.970 & 6.026 & $\begin{array}{l}68.856 \\
(0.000)\end{array}$ & 5.328 & 5.676 & $\begin{array}{l}7.414 \\
(0.007)\end{array}$ & $\begin{array}{c}1.579 \\
(0.210)\end{array}$ \\
\hline Identification & 4.311 & 4.766 & $\begin{array}{l}9.217 \\
(0.003)\end{array}$ & 4.522 & 4.558 & $\begin{array}{c}0.054 \\
(0.817)\end{array}$ & $\begin{array}{l}1.140 \\
(0.287)\end{array}$ \\
\hline Trust & 4.471 & 5.171 & $\begin{array}{l}33.888 \\
(0.000)\end{array}$ & 4.532 & 5.115 & $\begin{array}{l}23.363 \\
(0.000)\end{array}$ & $\begin{array}{c}4.098 \\
(0.044)\end{array}$ \\
\hline Purchase & 4.396 & 5.061 & $\begin{array}{l}16.998 \\
(0.000)\end{array}$ & 4.528 & 4.934 & $\begin{array}{l}6.313 \\
(0.013)\end{array}$ & $\begin{array}{c}0.134 \\
(0.715)\end{array}$ \\
\hline Advocacy & 4.433 & 5.548 & $\begin{array}{l}50.338 \\
(0.000)\end{array}$ & 4.620 & 5.369 & $\begin{array}{l}22.534 \\
(0.000)\end{array}$ & $\begin{array}{c}5.228 \\
(0.023)\end{array}$ \\
\hline
\end{tabular}

$F$-value (d.f. = 1), $p$-values in parentheses, type of service (utilitarian vs. hedonic), CSR discourse (expositive vs. narrative). 
As shown in Table 5, the findings indicated that the type of service (S) had a significant influence over all message attributions and consumer responses to CSR, whereas the discourse strategy (D) also had some significant influence over issue importance, CSR impact, CSR fit, CSR attributions, service brand attitudes, trust, purchase intentions, and advocacy intentions, but not over CSR motives, CSR commitment, or C-C identification. These three variables had similar means in the expositive and the narrative scenarios.

As for the interaction effect between the type of discourse and the type of service over message attributions, multivariate ANOVA detected a significant interaction for issue importance $(\mathrm{F}=8.228$, $p<0.050$ ) (Figure 1): the expositive discourse outperformed the narrative discourse in the bank context, whereas the narrative discourse outperformed the expositive discourse in the restaurant context. These results supported the hypotheses H1a and H2a. Similarly, results revealed a significant interaction, in the expected direction, for CSR fit ( $\mathrm{F}=14.590, p<0.050)$ (Figure 2). Therefore, the hypotheses H1d and H2d were supported. For CSR impact, CSR motives, and CSR commitment, multivariate ANOVA did not detect any significant interaction effect. However, as seen in Table 5, the discourse strategy had a significant effect over CSR impact, which was statistically higher for the narrative (vs. expositive) discourse ( $m e a n E=4.744$, meanN $=5.258 ; \mathrm{F}=17.419, p<0.050$ ). Therefore, the hypothesis $\mathrm{H} 2 \mathrm{~b}$ was supported by the findings, whereas the hypotheses H1b, H1c, H1e, H2c, and H2e were not supported.

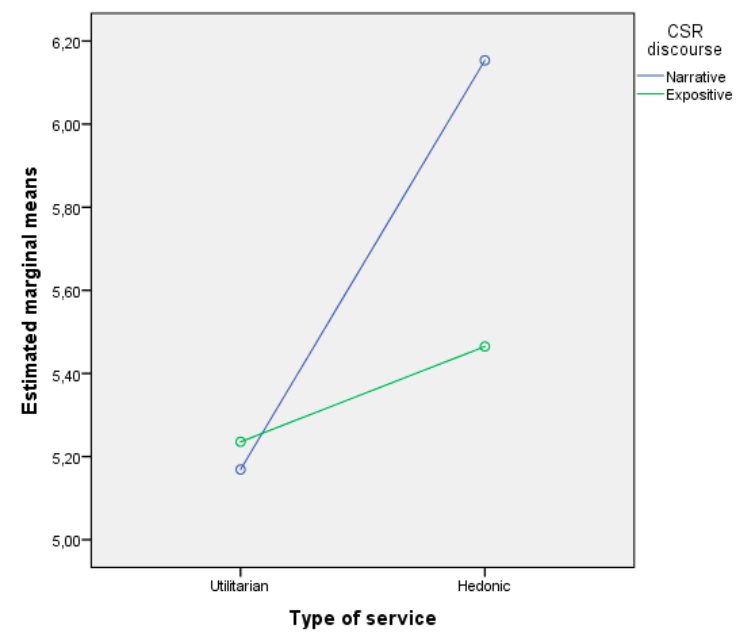

Figure 1. Effects of service type and discourse strategy on issue importance.

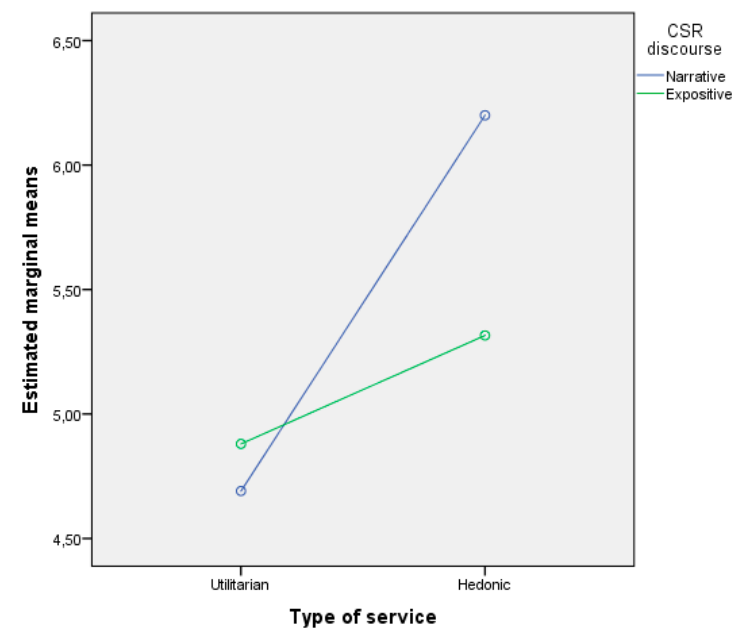

Figure 2. Effects of service type and discourse strategy on CSR fit. 
Concerning the interaction effect of discourse strategy and type of service over consumer responses to CSR, multivariate ANOVA results showed that a significant interaction existed for CSR attributions $(\mathrm{F}=6.823, p<0.050)$ (Figure 3$)$ : the expositive discourse outperformed the narrative discourse in the bank context, whereas the narrative discourse outperformed the expositive discourse in the restaurant context. These results supported the hypotheses H3a and H4a.

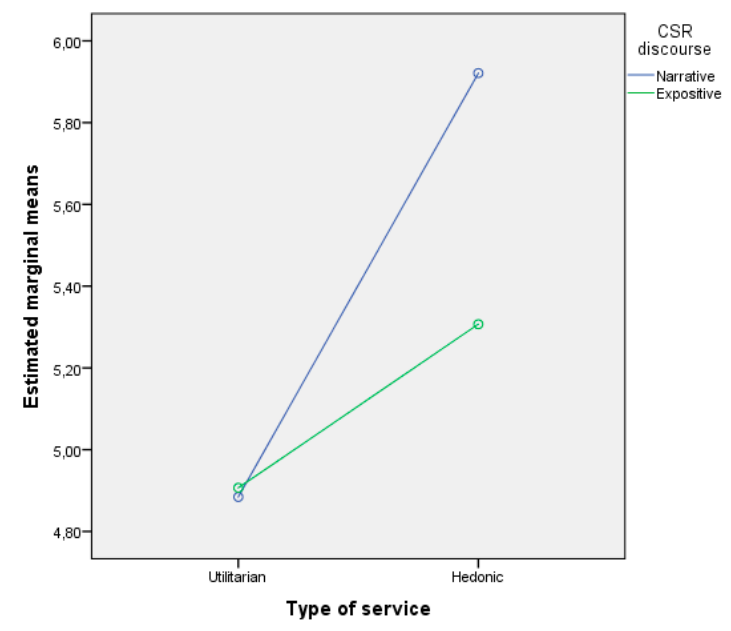

Figure 3. Effects of service type and discourse strategy on CSR attributions.

The analysis also detected interaction effects for trust $(\mathrm{F}=4.098, p<0.050)$ (Figure 4$)$ and advocacy intentions $(\mathrm{F}=5.228, p<0.050)$ (Figure 5). Nonetheless, in these two cases, the narrative discourse reported higher responses for both the utilitarian and the hedonic service. In these cases, the interaction effects highlighted that the difference in trust and advocacy intentions reported by the participants when exposed to the narrative (vs. expositive) discourse was statistically higher in the hedonic (vs. utilitarian) scenarios. Based on these results, then, the hypotheses H3d and H3f were not supported by the findings of the study, whereas the hypotheses H4d and H4f were supported.

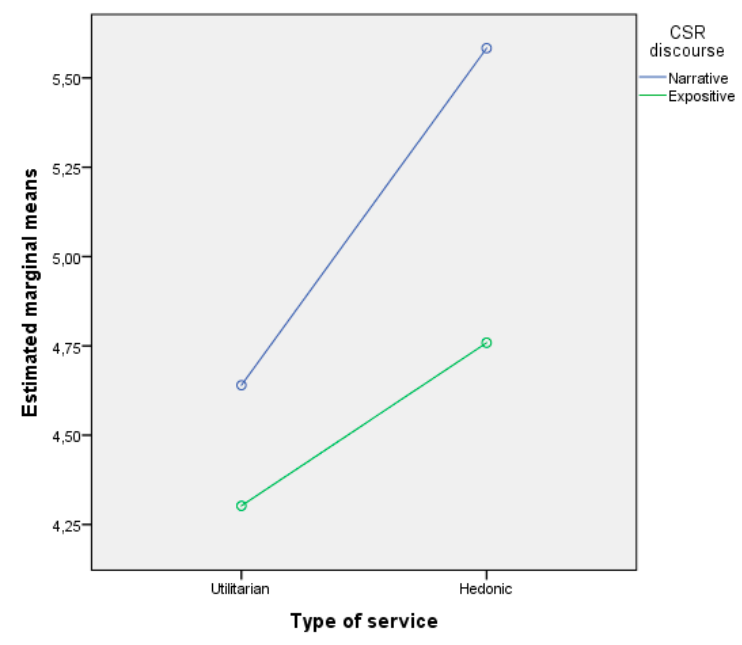

Figure 4. Effects of service type and discourse strategy on trust. 


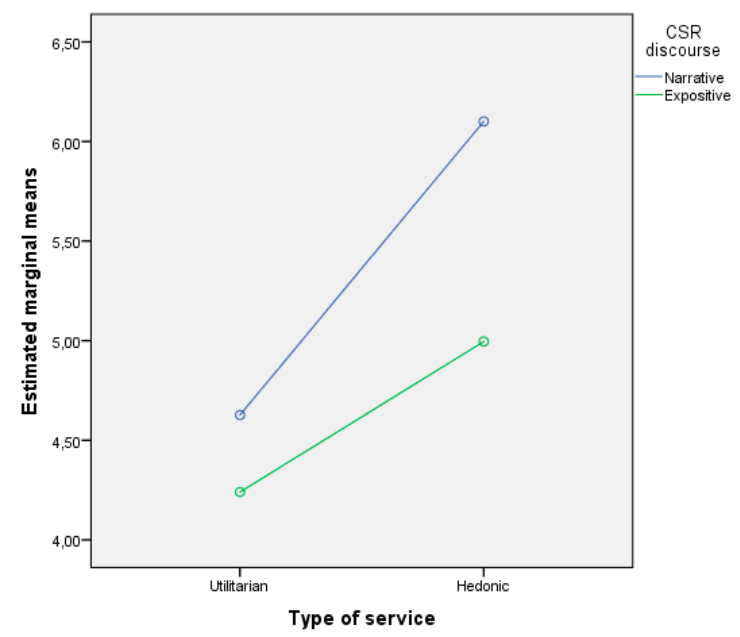

Figure 5. Effects of service type and discourse strategy on advocacy.

For service brand attitude, C-C identification and purchase intentions, multivariate ANOVA did not detect any significant interaction effect. However, as seen in Table 5, the discourse strategy had a significant effect over service brand attitude (meanE $=5.328$, meanN $=5.676 ; \mathrm{F}=7.414, p<0.050)$ and purchase intentions (meanE $=4.528$, meanN $=4.934 ; \mathrm{F}=6.313, p<0.050$ ), which were statistically higher for the narrative (vs. expositive) discourse. Therefore, the hypotheses H4b and H4e were supported by the findings, whereas the hypotheses $\mathrm{H} 3 \mathrm{~b}, \mathrm{H} 3 \mathrm{c}, \mathrm{H} 3 \mathrm{e}$, and $\mathrm{H} 4 \mathrm{c}$ were not supported.

\section{Discussion}

As a first interesting finding of this paper, the research shows that there were significant differences in message attributions and consumer responses across different types of services. In this regard, the catering service reported statistically significant higher valuations than the banking service for all the dependent variables in our conceptual model. This finding is not surprising as previous empirical literature in the services sector has already proved that hedonic services receive better outcomes from their communication strategies than utilitarian services $[16,17,77,78]$. Along this line, scholars have proposed that affect may provide a richer understanding of the experiential aspects of service consumption and such consumption emotion may even serve as a stronger motivator for purchase than utilitarian attributes [31]. Additionally, scholars also defend that experiential services are inherently more interesting to consumers than utilitarian services and, then, consumers are more involved with the category domain and more motivated to process promotional information [16,77]. Based on these ideas, research has mostly defended the superior role of hedonic services to generate more positive consumer responses [20], even to the point that several studies have demonstrated that, roughly speaking, any sort of corporate communication is frequently more effective for hedonic than utilitarian services $[16,17,77,78]$. Although this idea has been tested mostly in the context of conventional commercial communication, our paper contributes to this line of thought by corroborating the same finding in the context of CSR communication.

As for the effect of the type of discourse strategy on message attributions and consumer responses to CSR communication, our findings suggest that this is not as clear as the effect of the service type. On the contrary, here it is important to analyze the interaction effect between discourse strategy and type of service to get a better picture of the implications of choosing between an expositive and a narrative discourse when designing CSR communications. In this regard, our findings align with previous results in academic literature, as some empirical studies have also observed the difficulty to ascertain clear general conclusions derived from the application of different discourses [17].

For instance, there were no significant differences according to the type of discourse strategy for CSR motives, CSR commitment, and C-C identification. A possible explanation is that these three variables were among the lowest-rated attributes of CSR communication in the diverse scenarios 
explored in the study. Even though the two types of discourses evaluated in the study elicited positive outcomes in most of the message attributions and consumer responses, they were not able to transmit enough altruism nor enough long-term commitment on the part of the company to collaborate in the specific leukemia cause. This finding reinforces the arguments of previous scholars who have defended that consumers are highly skeptical of companies and their CSR activities [79], which undermines the power of CSR communication to transmit altruistic motives and long-term commitment for the company-cause collaboration, even if the company relies on narrative messages to communicate its CSR activities through storytelling. Similarly, C-C identification was the lowest-rated consumer response in both the expositive and narrative scenarios. This result may be explained by the utilization of fictitious information (companies and social cause) for the experiment. As it has happened in other studies, to feel identified with a company and its CSR efforts, consumers must cognitively categorize themselves as members of the company (i.e., actual customers). Awareness of belonging and connection to a company is a way for consumers to achieve a positive social identity and, as a consequence of this sense of connection, the company is psychologically accepted as part of that personal identity and the consumer feels identified with it [80]. However, when analyzing fictitious companies in experiments, participants do not have the time to develop a strong connection to the company and, as so, C-C identification ranks low.

The superiority of expositive (vs. narrative) discourses for utilitarian services was confirmed only for issue importance, CSR fit, and CSR attributions, whereas the superiority of narrative (vs. expositive) discourses for hedonic services was proved for issue importance, CSR impact, CSR fit, CSR attributions, service brand attitude, trust, purchase, and advocacy intentions. Indeed, in most cases, the results showed that, in both the banking and restaurant contexts, message attributions and responses to CSR communication were significantly higher when consumers were exposed to the narrative discourse. This was especially the case for CSR impact, service brand attitude, and purchase intentions, for which no interaction effect between discourse strategy and service type was observed. For the three variables, the narrative discourse always reported better results than the expositive discourse for both the utilitarian and the hedonic services. This finding was also corroborated for trust and advocacy intentions and the findings in these cases are especially worth mentioning. For trust and advocacy intentions, the interaction effect between discourse strategy and service type was significant but it worked in a different direction than our previous expectations. Consumers reported higher trust and advocacy intentions when exposed to the narrative discourse in banking and restaurant scenarios. Nonetheless, in these two cases, the difference between using an expositive and a narrative discourse was notably higher in the hedonic condition than in the utilitarian condition. This finding suggests that making a wrong decision when choosing the discourse strategy (i.e, selecting an expositive message instead of a narrative one) would be more damaging to a company commercializing hedonic services than utilitarian services. In doing so, hedonic services face the risk of losing a greater amount of trust and advocacy intentions than a company commercializing utilitarian services taking the same decision.

Although these findings do not fully align with the principles of the ELM defended in previous literature, an interesting explanation for them may be found in the arguments provided by Stafford (1996) concerning the use of documentation strategies for corporate communication [77]. A documentation strategy refers to the provision of facts and figures within corporate messages that explain or demonstrate the benefits, value, quality, or advantages of the information provided [17]. As reported in her study, using a documentation strategy has positive effects on consumer responses in hedonic settings, whereas it has no significant effects in terms of informativeness, uniqueness, perceived quality, or likelihood to use the service in utilitarian service contexts [77]. In our experiment, the expositive and narrative scenarios used the same documentation strategy (i.e., the same facts, numbers, etc.), while the findings reported that the matching principle fitted the narrative-hedonic combination much better than the expositive-utilitarian combination. More precisely, while 8 sub hypotheses of the 11 initially proposed were supported by our findings for the restaurant context, only 3 out of 11 sub hypotheses were supported for the banking service. Therefore, the findings seem to corroborate the more positive 
effect of documentation in the hedonic context. In this regard, Singh and Dalal (1999) defend that, regardless of their nature, all corporate messages 'inform' because they create awareness, impressions, knowledge, and beliefs about services, companies, and messages [24]. Thus, the difference in corporate communication depends largely on the emotional connection that it establishes between the company and consumers.

Under these premises, it is also easy to understand why the narrative discourse outperformed the expositive discourse in our study, even in the utilitarian conditions. It seems that, along with documentation features, adding visualization elements (e.g., narrative discourses based on storytelling) to corporate communication [17] generates a favorable general context for communication, which aligns with the principles of the NPT [11]. According to this theory, corporate stories activate narrative rationality, making the information contained in the message more salient, accessible, and intelligible for consumers to interpret and assess the message [7]. This theory suggests that well-designed and well-told stories not only convey information but they also convey emotion [32], which enhances the potential of the message to make its information more real to consumers, easier to remember and more convincing [12,81]. Not in vain, Mortimer (2008) showed how the majority of successful advertisements utilize emotional appeals for not only experiential but also utilitarian services [15]. Therefore, our findings align with those of Mortimer (2008), as she also detects that narrative discourses can be adequate for both utilitarian and hedonic services.

The superior performance of narrative over expositive discourses in our paper can also be justified by the communication context explored in the study. More precisely, we analyzed consumer responses to CSR communication that, in itself, is more affective and emotional than conventional commercial communications such as advertising. As opposed to commercial advertising, CSR communication does not directly seek to "sell" a product/service. CSR communication is institutional communication that mostly seeks to improve corporate image. Therefore, emotional elements in the message may be more important to the consumer than the functional, objective elements when evaluating CSR communication. This idea is supported by the insights provided by previous scholars such as Batra and Ahtola (1990) or Kempf (1999) [20,82]. More precisely, Batra and Ahtola (1990) showed that consumer attitudes are compounded of two distinct dimensions, hedonic and utilitarian attitudes, and that different service attributes contribute to each dimension differently [82]. For instance, experiential sensory attributes are closely associated with the hedonic component of attitude, whereas more functional attributes are associated with the utilitarian part of attitude [20]. Along this line, it can be argued that CSR is a hedonic attribute of the company, which especially affects the hedonic component of consumer responses and, as so, fits into the narrative-hedonic matching principle proposed in this paper much better than functional, rational attributes.

\section{Conclusions, Implications, Limitations, and Future Lines of Research}

The main goal of this paper has been to determine whether the use of expositive versus narrative discourses interacts with the type of service commercialized by a company to determine consumer perceptions and responses to CSR communication. For this purpose, we have developed a conceptual model based on the theoretical framework of CSR communication of Du et al. (2010) that we have tested empirically with a sample of consumers who have evaluated a fictitious CSR message coming from a banking and a catering company, respectively. In this regard, although research from diverse disciplines has defended an interaction effect between the discourse strategy and the service context, scholars have scarcely explored this idea in the CSR context, where a significant gap exists between the theory and practice of CSR communication. This scarcity of previous literature highlights the contribution of our paper.

The findings of the paper demonstrate that the matching principle suggested by the ELM does not apply as clearly to the context of CSR communication as it does to conventional commercial communication (e.g., advertising). As expected, it is confirmed that for hedonic services, narrative discourses outperform expositive discourses in terms of message attributions and consumer attitudinal 
(i.e., internal) and behavioral (i.e., external) responses to CSR communication. Nonetheless, and in accordance with the NPT, the use of narrative discourses can also be useful for utilitarian services as they also generate some better message attributions (i.e., CSR impact) and consumer responses (i.e., service brand attitude, trust, purchase, and advocacy intentions) than expositive discourses. Unfortunately, the findings also show that companies that commercialize utilitarian services, such as banking companies, do not profit from CSR communication as much as companies in the context of hedonic services. In our study, the bank reaped more modest responses to its CSR efforts than the restaurant. Along this line, the findings demonstrate that the choice between expositive and narrative discourses has a noticeably higher effect on consumer responses in hedonic than utilitarian contexts, indicating that the decision of the type of discourse strategy to follow is more strategic for hedonic than utilitarian services.

Based on these findings, we highlight some managerial implications that could help companies improve their CSR communication.

In this regard, the most significant implication of the study relates to the benefits that companies can gain by presenting CSR through attractive and compelling stories, especially in the context of hedonic services. CSR stories make social causes real to the audience, they reframe arguments in an easy-to-grasp and easy-to-remember format and they make messages memorable in multiple ways (visually, factually, and emotionally) [26]. In doing so, CSR storytelling generates an emotional connection between the audience and the company $[26,27]$ and, consequently, it intensifies consumer positive attitudes and responses to CSR messages $[64,83]$. This way of presenting CSR information matches the characteristics of hedonic services especially well as hedonic services are characterized by affective gratification purposes [20] and they mostly provide consumers with emotions [31]. Therefore, we recommend that companies that commercialize hedonic services design CSR messages based on storytelling instead of using expositive discourses that lack emotional bases to engage consumers. Nonetheless, recent studies have identified that companies are missing opportunities to maximize the impact of narrative discourse strategies, especially in the online context [15,81]. More precisely, storytelling is a relatively unpopular form of communication in companies' websites, as very few companies and brands use it $[81,84,85]$. The scarcity of stories in corporate communication is especially evident in the context of CSR communication, where companies have only recently started to transmit messages through storytelling [86].

In the case of utilitarian services, companies should first decide the communication objectives they want to prioritize and, based on that, select the best discourse strategy to achieve those goals. If the objective is to improve the overall CSR image of the company (i.e., CSR attributions), or improve the visibility of the social cause (i.e., issue importance), companies such as banks should better use an expositive discourse. On the contrary, if they want to focus on consumer behavioral responses (i.e., purchase, advocacy), it is best to use a narrative discourse.

One additional implication, which can benefit both utilitarian and hedonic services, relates to the messages attributions that companies should try to improve in their future CSR communication. On the one hand, the findings of the present study demonstrate that CSR motives are the most poorly rated attributions in CSR communication. Consumers have demonstrated to be highly skeptical of corporate motives to relate to social causes; they have a natural tendency to perceive egoism behind company-cause connections [87]. Nonetheless, avoiding skepticism and improving motives attribution is key to success in CSR communication, as this variable relates closely to consumer behavior such as purchase, advocacy, and loyalty intentions [88]. Therefore, companies must focus their CSR messages on providing convincing reasoning for their motives to engage with social causes, which should be as altruistic as possible to reduce consumer skepticism and improve their support responses. On the other hand, companies should also focus on improving C-C identification, which rated notably low in all the conditions of our experiment. C-C identification has been proved to be an essential attitudinal response to CSR communication that derives in positive outcomes for companies, including trust, satisfaction and loyalty [50]. 
Finally, this study is not without limitations and future research should consider them to improve our knowledge of CSR communication. First, the use of fictitious companies and fictitious CSR messages can limit the generalization of our findings. Future studies should explore consumer responses to the CSR communication of real companies to determine whether our research findings also apply to CSR messages and consumers in real contexts. Second, future research should also focus on studying additional interaction effects between discourse strategy and other variables that may affect message attributions and consumer responses to CSR communication more intensively than the discourse-service match tested in this paper. For instance, an interesting interaction effect could emerge between discourse strategy and the CSR stimulus (i.e., social cause) chosen by the company as the focus of its CSR efforts [21]. Then, we suggest that future authors test our conceptual model for diverse social causes to corroborate (or not) our findings. In addition, previous research has suggested that the type of CSR support provided by companies (i.e., monetary vs. in-kind support) may affect consumer responses to CSR messages in CSR communication [89]. Consumers tend to react to in-kind support more favorably than to monetary support [89] and this fact may determine the effect of different discourse strategies. In testing these ideas, we suggest that scholars delve further into CSR literature to build their arguments. Given the differences between conventional commercial communication and CSR communication, we believe that scholars can develop hypotheses that are more accurate if they base their arguments on CSR theories instead of grounding them solely on communication and advertising literature.

Author Contributions: Conceptualization, A.P. and E.B.-D.; methodology, A.P. and M.d.M.G.d.l.S.; software, A.P.; validation, A.P., M.d.M.G.d.l.S. and E.B.-D.; writing-original draft preparation, A.P., M.d.M.G.d.l.S. and E.B.-D.; writing-review and editing, A.P., M.d.M.G.d.l.S. and E.B.-D. All authors have read and agreed to the published version of the manuscript.

Funding: This research received no external funding.

Conflicts of Interest: The authors declare no conflict of interest.

\section{Appendix A. Website Stimuli Evaluated by the Participants}
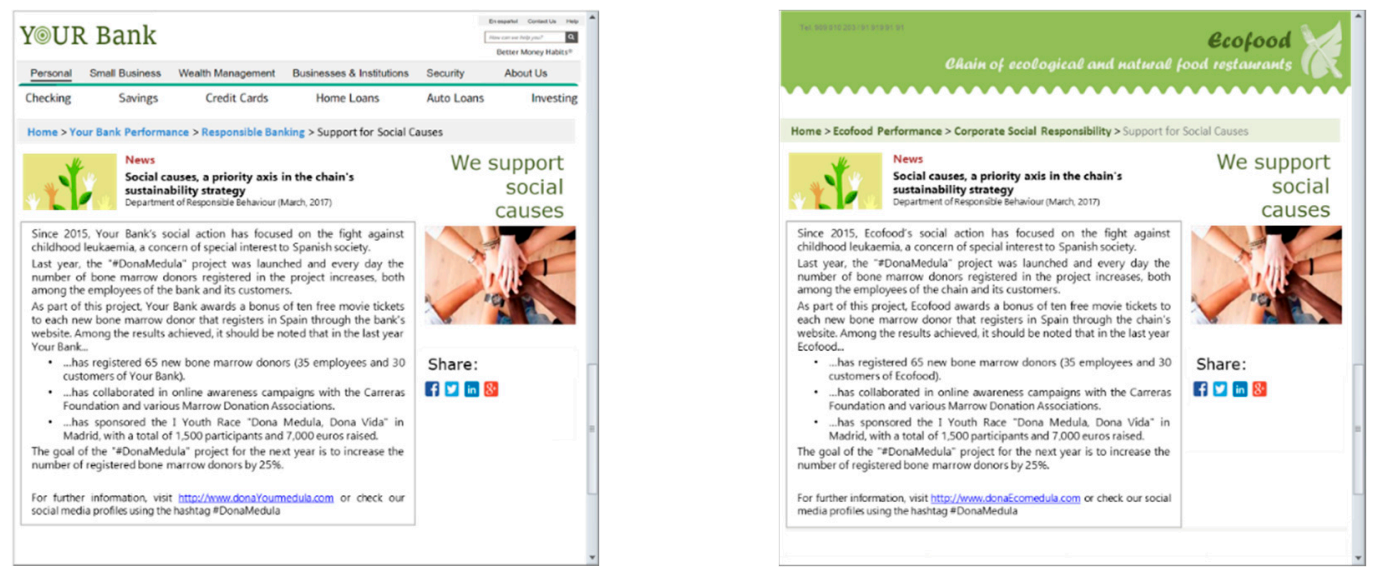

Figure A1. Expositive discourse strategy. Website A (utilitarian service), Website B (hedonic service). 

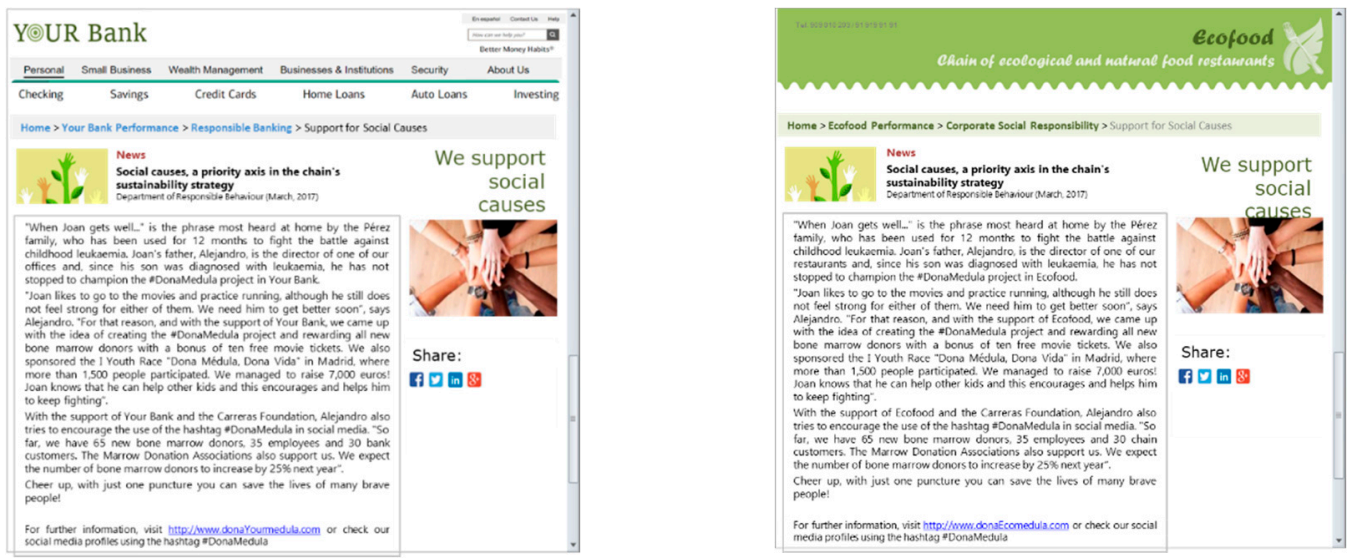

Figure A2. Narrative discourse strategy. Website C (utilitarian service), Website D (hedonic service).

\section{References}

1. Mason, C.; Simmons, J. Forward looking or looking unaffordable? Utilising academic perspectives on corporate social responsibility to assess the factors influencing its adoption by business. Bus. Ethics $A$ Eur. Rev. 2011, 20, 159-176. [CrossRef]

2. Liang, $\mathrm{X} . ; \mathrm{Hu}, \mathrm{X}$; Meng, H. Truly sustainability or hypocrisy: The effects of corporate sustainable orientation on consumers' quality perception and trust based on evidence from China. Sustainability 2020, 12, 2735. [CrossRef]

3. Ahmed, I.; Nazir, M.S.; Ali, I.; Nurunnabi, M.; Khalid, A.; Shaukat, M.Z. Investing in CSR pays you back in many ways! The case of perceptual, attitudinal and behavioral outcomes of customers. Sustainability 2020, 12, 1158. [CrossRef]

4. Du, S.; Bhattacharya, C.B.; Sen, S. Maximizing business returns to corporate social responsibility (CSR): The role of CSR communication. Int. J. Manag. Rev. 2010, 12, 8-19. [CrossRef]

5. Skarmeas, D.; Leonidou, C.N. When consumers doubt, watch out! The role of CSR skepticism. J. Bus. Res. 2012, 66, 1831-1838. [CrossRef]

6. Martin, J.; Powers, M. Organizational stories: More vivid and persuasive than quantitative data. In Psychological Foundations of Organizational Behavior; Foresman: Glenview, IL, USA, 1983; pp. 162-168.

7. Weick, K.E.; Browning, L.D. Argument and narration in organizational communication. J. Manag. 1986, 12, 243-259. [CrossRef]

8. Martin, J. Stories and scripts in organizational settings. In Cognitive Social Psychology; Elsevier: New York, NY, USA, 1982; pp. 255-305.

9. Lewis, N.; Sznitman, S.R. You brought it on yourself: The joint effects of message type, stigma, and responsibility attribution on attitudes toward medical cannabis. J. Commun. 2017, 67, 181-202. [CrossRef]

10. Murphy, S.T.; Frank, L.B.; Chatterjee, J.S.; Baezconde-Garbanati, L. Narrative versus nonnarrative: The role of identification, transportation and emotion in reducing health disparities. J. Commun. 2013, 63, 116-137. [CrossRef] [PubMed]

11. Fisher, W.R. The narrative paradigm: An elaboration. Commun. Monogr. 1985, 52, 347-367. [CrossRef]

12. Kaufman, B. Stories that sell, stories that tell. J. Bus. Strategy 2003, 24, 11-15. [CrossRef]

13. Woodside, A.G. Brand-consumer storytelling theory and research: Introduction to a Psychology \& Marketing speciall issue. Psychol. Mark. 2010, 27, 531-540.

14. Lundqvist, A.; Liljander, V.; Gummerus, J.; van Riel, A. The impact of storytelling on the consumer brand experience: The case of a firm-originated story. J. Brand Manag. 2013, 20, 283-297. [CrossRef]

15. Mortimer, K. Identifying the components of effective service advertisements. J. Serv. Mark. 2008, 22, 104-113. [CrossRef]

16. Stafford, M.R.; Day, E. Retail services advertising: The effects of appeal, medium, and service. J. Advert. 1995, 24, 37-41. [CrossRef] 
17. Hill, D.J.; Blodgett, J.; Baer, R.; Wakefield, K. An investigation of visualization and documentation strategies in services advertising. J. Serv. Res. 2004, 7, 155-166. [CrossRef]

18. Johar, J.S.; Sirgy, M.J. Value-expressive versus utilitarian advertising appeals: When and why to use which appeal. J. Advert. 1991, 20, 23-33. [CrossRef]

19. Albers-Miller, N.D.; Stafford, M.R. International services advertising: An examination of variation in appeal use for experiential and utilitarian services. J. Serv. Mark. 1999, 13, 390-406. [CrossRef]

20. Kempf, D.S. Attitude formation from product trial: Distinct roles of cognition and affect for hedonic and functional products. Psychol. Mark. 1999, 16, 35-50. [CrossRef]

21. Andreu, L.; Casado-Díaz, A.B.; Mattila, A.S. Effects of message appeal and service type in CSR communication strategies. J. Bus. Res. 2015, 68, 1488-1495. [CrossRef]

22. Yang, C.-M.; Hsu, T.-F. Effects of skepticism about corporate social responsibility advertising on consumer attitude. Soc. Behav. Pers. 2017, 45, 453-468. [CrossRef]

23. Petty, R.E.; Cacioppo, J.T. Attitudes and Persuasion: Classic and Contemporary Approaches; William C. Brown: Dubuque, IO, USA, 1981.

24. Singh, S.N.; Dalal, N.P. Web home pages as advertisements. Commun. ACM 1999, 42, 91-98. [CrossRef]

25. Gill, R. An integrative review of storytelling: Using corporate stories to strengthen employee engagement and internal and external reputation. Prism 2011, 8, 1-16.

26. Escalas, J.E. Narrative processing: Building consumer connections to brands. J. Consum. Psychol. 2004, $14,168-180$.

27. Herskovitz, S.; Crystal, M. The essential brand persona: Storytelling and branding. J. Bus. Strategy 2010, 31, 21-28. [CrossRef]

28. Zak, P.J. Why your brain loves good storytelling. Harv. Bus. Rev. 2014, 28, 1-5.

29. Pérez, A.; del Mar García de los Salmones, M.; López-Gutiérrez, C. Corporate reputation in the Spanish context: An interaction between reporting to stakeholders and industry. J. Bus. Ethics 2015, 129, 733-746.

30. Um, N.H. Revisit elaboration likelihood model: How advertising appeals work on attitudinal and behavioural brand loyalty centering around low vs. high involvement product. Eur. J. Soc. Sci. 2008, 7, 126-139.

31. Jiang, Y.; Lu Wang, C. The impact of affect on service quality and satisfaction: The moderation of service contexts. J. Serv. Mark. 2006, 20, 211-218. [CrossRef]

32. Sole, D.; Wilson, D.G. Storytelling in Organizations: The Power and Traps of Using Stories to Share Knowledge in Organizations; Harvard Graduate School of Education: Cambridge, MA, USA, 2002.

33. Aldama, F.L. The Science of storytelling: Perspectives from cognitive science, neuroscience, and the humanities. Projections 2015, 9, 80-95. [CrossRef]

34. Pérez, A.; del Mar García de los Salmones, M.; Liu, M.T. Maximising business returns to corporate social responsibility communication: An empirical test. Bus. Ethics A Eur. Rev. 2019, 28, 275-289.

35. Pomering, A.; Johnson, L.W. Advertising corporate social responsibility initiatives to communicate corporate image: Inhibiting scepticism to enhance persuasion. Corp. Commun. An Int. J. 2009, 14, 420-439. [CrossRef]

36. Menon, S.; Kahn, B. Corporate sponsorships of philanthropic activities: When do they impact perception of sponsor brand? J. Consum. Psychol. 2003, 13, 316-327. [CrossRef]

37. Bhattacharya, C.B.; Korschun, D.; Sen, S. Strengthening stakeholder-company relationships through mutually beneficial corporate social responsibility initiatives. J. Bus. Ethics 2009, 85, 257-272. [CrossRef]

38. Parguel, B.; Benoit-Moreau, F.; Larceneux, F. How sustainability ratings might deter "greenwashing": A closer look at ethical corporate communication. J. Bus. Ethics 2011, 102, 15-28. [CrossRef]

39. García de los Salmones, M.M.; Pérez, A. Effectiveness of CSR advertising: The role of reputation, consumer attributions, and emotions. Corp. Soc. Responsib. Environ. Manag. 2018, 25, 194-208. [CrossRef]

40. van Rekom, J.; van Riel, C.B.M.; Wierenga, B. A methodology for assessing organizational core values. J. Manag. Stud. 2006, 43, 175-201. [CrossRef]

41. Maignan, I.; Ralston, D.A. Corporate social responsibility in Europe and the U.S.: Insights from businesses' self-presentations. J. Int. Bus. Stud. 2002, 33, 497-514. [CrossRef]

42. Lafferty, B.A.; Goldsmith, R.E.; Hult, G.T.M. The impact of the alliance on the partners: A look at cause-brand alliances. Psychol. Mark. 2004, 21, 509-531. [CrossRef]

43. Trimble, C.S.; Rifon, N.J. Consumer perceptions of compatibility in cause-related marketing messages. Int. J. Nonprofit Volunt. Sect. Mark. 2006, 11, 29-47. [CrossRef] 
44. Bigné, E.; Chumpitaz, R.; Currás, R. Alliances between brands and social causes: The influence of company credibility on social responsibility image. J. Bus. Ethics 2010, 96, 169-186.

45. Rifon, N.J.; Choi, S.M.; Trimble, C.S.; Li, H. Congruence effect in sponsorship: The mediating role of sponsor credibility and consumer attributions of sponsor motive. J. Advert. 2004, 33, 29-42. [CrossRef]

46. Benoit-Moreau, F.; Parguel, B. Building brand equity with environmental communication: An empirical investigation in France. EuroMed J. Bus. 2011, 6, 100-116. [CrossRef]

47. Keller, K.L. Strategic Brand Management; Prentice-Hall: Upper Saddle River, NJ, USA, 1998.

48. O'Cass, A.; Grace, D. Exploring consumer experiences with a service brand. J. Prod. Brand Manag. 2004, 13, 257-268. [CrossRef]

49. Bravo, R.; Matute, J.; Pina, J.M. Corporate social responsibility as a vehicle to reveal the corporate identity: A study focused on the websites of Spanish financial entities. J. Bus. Ethics 2012, 107, 129-146. [CrossRef]

50. Pérez, A.; del Mar García de los Salmones, M.; Rodríguez del Bosque, I. The effect of corporate associations on consumer behaviour. Eur. J. Mark. 2013, 47, 218-238.

51. Garcia de los Salmones, M.M.; Perez, A.; Rodriguez del Bosque, I. The social role of financial companies as a determinant of consumer behaviour. Int. J. Bank Mark. 2009, 27. [CrossRef]

52. Morgan, R.M.; Hunt, S.D. The commitment-trust theory of relationship marketing. J. Mark. 1994, 58, $20-38$. [CrossRef]

53. Chiou, J.-S.; Droge, C. Service quality, trust, specific asset investment, and expertise: Direct and indirect effects in a satisfaction-loyalty framework. J. Acad. Mark. Sci. 2006, 34, 613-627. [CrossRef]

54. Lewis, B.R.; Soureli, M. The antecedents of consumer loyalty in retail banking. J. Consum. Behav. 2006, 5, 15-31. [CrossRef]

55. Oliver, R.L. Satisfaction: A Behavioral Perspective on the Consumer; McGraw-Hill: New York, NY, USA, 1997.

56. Oliver, R.L. Whence consumer loyalty? J. Mark. 1999, 63, 33-44. [CrossRef]

57. Khan, Z.; Ferguson, D.; Pérez, A. Customer responses to CSR in the Pakistani banking industry. Mark. Intell. Plan. 2015, 33. [CrossRef]

58. Westbrook, R.A. Product/consumption-based affective responses and postpurchase processes. J. Mark. Res. 1987, 24, 258-270. [CrossRef]

59. Kim, Y. Strategic communication of corporate social responsibility (CSR): Effects of stated motives and corporate reputation on stakeholder responses. Public Relat. Rev. 2014, 40, 838-840. [CrossRef]

60. Nan, X.; Heo, K. Consumer responses to Corporate Social Responsibility (CSR) initiatives: Examining the role of brand-cause fit in cause-related marketing. J. Advert. 2007, 36, 63-74. [CrossRef]

61. Alniacik, U.; Alniacik, E.; Genc, N. How corporate social responsibility information influences stakeholders' intentions. Corp. Soc. Responsib. Environ. Manag. 2011, 18, 234-245. [CrossRef]

62. Currás, R. Comunicación de la Responsabilidad Social Corporativa: Imagen e Identificación con la Empresa como Antecedentes del Comportamiento del Consumidor; Universitat de València: Valencia, Spain, 2007.

63. Ladhari, R.; Souiden, N.; Dufour, B. The role of emotions in utilitarian service settings: The effects of emotional satisfaction on product perception and behavioral intentions. J. Retail. Consum. Serv. 2017, 34, 10-18. [CrossRef]

64. Chiu, H.-C.; Hsieh, Y.-C.; Kuo, Y.-C. How to align your brand stories with your products. J. Retail. 2012, 88, 262-275. [CrossRef]

65. Mohr, L.A.; Eroǧlu, D.; Ellen, P.S. The development and testing of a measure of skepticism toward environmental claims in marketers' communications. J. Consum. Aff. 1998, 32, 30-55. [CrossRef]

66. Russell, D.W.; Russell, C.A. Here or there? Consumer reactions to corporate social responsibility initiatives: Egocentric tendencies and their moderators. Mark. Lett. 2010, 21, 65-81. [CrossRef]

67. Connors, S.; Anderson-MacDonald, S.; Thomson, M. Overcoming the 'window dressing' effect: Mitigating the negative effects of inherent skepticism towards corporate social responsibility. J. Bus. Ethics 2017, 145, 599-621. [CrossRef]

68. Becker-Olsen, K.L.; Cudmore, B.A.; Hill, R.P. The impact of perceived corporate social responsibility on consumer behavior. J. Bus. Res. 2006, 59, 46-53. [CrossRef]

69. Speed, R.; Thompson, P. Determinants of sport sponsorship response. J. Acad. Mark. Sci. 2000, 28, $226-238$. [CrossRef]

70. Skard, S.; Thorbjørnsen, H. Is publicity always better than advertising? The role of brand reputation in communicating corporate social responsibility. J. Bus. Ethics 2014, 124, 149-160. [CrossRef] 
71. Walton, M.R. The PR in CSR: Assessing Perceptions of Partnerships Versus Donations in Corporate Social Responsibility Initiatives; Texas A\&M University: Canyon, TX, USA, 2014.

72. Wagner, T.; Lutz, R.J.; Weitz, B.A. Corporate hypocrisy: Overcoming the threat of inconsistent corporate social responsibility perceptions. J. Mark. 2009, 73, 77-91. [CrossRef]

73. Groza, M.D.; Pronschinske, M.R.; Walker, M. Perceived organizational motives and consumer responses to proactive and reactive CSR. J. Bus. Ethics 2011, 102, 639-652. [CrossRef]

74. Romani, S.; Grappi, S.; Bagozzi, R.P. Explaining consumer reactions to corporate social responsibility: The role of gratitude and altruistic values. J. Bus. Ethics 2013, 114, 193-206. [CrossRef]

75. Podsakoff, P.M.; MacKenzie, S.B.; Lee, J.Y.; Podsakoff, N.P. Common method biases in behavioral research: A critical review of the literature and recommended remedies. J. Appl. Psychol. 2003, 88, 879-903. [CrossRef]

76. Hair, J.F.; Black, W.C.; Babin, B.J.; Anderson, R.E. Multivariate Data Analysis, 7th ed.; Pearson Education Limited: Harlow, UK, 2014.

77. Stafford, M.R. Tangibility in services advertising: An investigation of verbal versus visual cues. J. Advert. 1996, 25, 13-28. [CrossRef]

78. Wakefield, K.L.; Inman, J.J. Situational price sensitivity: The role of consumption occasion, social context and income. J. Retail. 2003, 79, 199-212. [CrossRef]

79. Forehand, M.R.; Grier, S. When is honesty the best policy? The effect of stated company intent on consumer skepticism. J. Consum. Psychol. 2003, 13, 349-356.

80. Currás, R.; Bigné, E.; Alvarado, A. The role of self-definitional principles in consumer identification with a socially responsible company. J. Bus. Ethics 2009, 89, 547-564. [CrossRef]

81. Delgado-Ballester, E.; Fernández-Sabiote, E. Once upon a brand: Storytelling practices by Spanish brands. Spanish J. Mark.-ESIC 2016, 20, 115-131. [CrossRef]

82. Batra, R.; Ahtola, O.T. Measuring the hedonic and utilitarian sources of consumer attitudes. Mark. Lett. 1990, 2, 159-170. [CrossRef]

83. van Laer, T.; de Ruyter, K.; Visconti, L.M.; Wetzels, M. The extended transportation-imagery model: A meta-analysis of the antecedents and consequences of consumers' narrative transportation. J. Consum. Res. 2014, 40, 797-817. [CrossRef]

84. Spear, S.; Roper, S. Using corporate stories to build the corporate brand: An impression management perspective. J. Prod. Brand Manag. 2013, 22, 491-501. [CrossRef]

85. Du, S.; Vieira, E.T. Striving for legitimacy through corporate social responsibility: Insights from oil companies. J. Bus. Ethics 2012, 110, 413-427. [CrossRef]

86. Gill, R. Why the PR strategy of storytelling improves employee engagement and adds value to CSR: An integrated literature review. Public Relat. Rev. 2015, 41, 662-674. [CrossRef]

87. Bigné, E.; Currás, R.; Sánchez, I. Brand credibility in cause-related marketing: The moderating role of consumer values. J. Prod. Brand Manag. 2009, 18, 437-447. [CrossRef]

88. Pérez, A.; del Bosque, I.R. How customer support for corporate social responsibility influences the image of companies: Evidence from the banking industry. Corp. Soc. Responsib. Environ. Manag. 2015, 22. [CrossRef]

89. Hildebrand, D.; Demotta, Y.; Sen, S.; Valenzuela, A. Consumer responses to corporate social responsibility (CSR) contribution type. J. Consum. Res. 2017, 44, 738-758. [CrossRef]

(C) 2020 by the authors. Licensee MDPI, Basel, Switzerland. This article is an open access article distributed under the terms and conditions of the Creative Commons Attribution (CC BY) license (http://creativecommons.org/licenses/by/4.0/). 